\title{
Feeding preferences and seasonality of free-living marine nematodes inhabiting the kelp Macrocystis integrifolia
}

\author{
D. B. Trotter and J. M. Webster \\ Department of Biological Sciences, Simon Fraser University, Burnaby, Vancouver, B. C. V5A 1S6, Canada
}

\begin{abstract}
The 3 predominant nematode species found on Macrocystis integrifolia on the Canadian Pacific coast, Prochromadorella neapolitana, Monhystera refringens and $M$. disjuncta, showed specific responses to bacterial and diatomaceous food sources in feeding experiments under simulated summer and winter conditions. P. neapolitana exhibited a definite preference for diatoms, particularly Cocconeis scutellum and Gramatophora marina, over bacteria. M. refringens showed no general preference towards either bacteria or diatoms but exhibited some particular preference for the diatom Synedra tabulata. Under both environmental simulations, $M$ disjuncta showed a marked preference for bacteria and especially for one of the rod-shaped species. The seasonal abundance and distribution of these nematodes is discussed in relation to the seasonality of their bacterium and diatom food sources.
\end{abstract}

\section{INTRODUCTION}

Trophic relationships of the marine meiofauna are complex. Marine nematodes are no exception in their diversity of feeding patterns. This resulted in a classification of free-living nematodes based on their respective feeding habits (Wieser, 1952).

A study of the nematode fauna associated with kelp holdfasts classified $52 \%$ of the species as omnivores, $24 \%$ as epigrowth feeders, $18 \%$ as selective deposit feeders and $6 \%$ as unselective deposit feeders (Moore, 1971). These results indicate that the most important sources of food were the epibiota growing on the kelp and that the sparse occurrence of deposit feeders reflected a scarcity of suitable deposits within the holdfast habitat. The distribution of these food-source organisms is greatly influenced by local geographical features and by the productivity of the environment which, in turn, influences the distribution of nematode species. Observations from an experimental sand ecosystem revealed that the vertical zonations of the marine nematode population varied directly with relative bacterial numbers (Boucher and Chamroux, 1976). There are, however, no published studies showing the specific natural food preferences of benthic nematodes associated with kelp and their relationship with nematode distribution.
On the Canadian Pacific coast, 3 species of freeliving marine nematodes occur commonly on the blades of the kelp Macrocystis integrifolia Bory: Prochromadorella neapolitana, Monhystera refringens and $M$. disjuncta; the general features of their distribution over time and space is known (Trotter, 1981). Preliminary observations suggested that nematode population peaks might be associated with the relative abundance of a particular food source. Hence, the objectives of this study were to determine the nematode food preferences using diatoms and bacteria isolated from $M$. integrifolia blades, and to relate these findings to their seasonality and distribution on $M$. integrifolia blades.

\section{MATERIAL AND METHODS}

Living nematodes were collected from middle and lower blades of Macrocystis integrifolia Bory, from January to July 1980, separated from debris and other organisms by sieving, and then transferred to $105 \mathrm{~cm}^{2}$ Corning Tissue Flasks, containing $400 \mathrm{ml}$ of filtered seawater and several small pieces of $M$. integrifolia blade. The 3 most abundant nematode species were isolated from these cultures after 2 wk and each species was cultured separately in flasks containing 
only detritus and pieces of $M$. integrifolia in autoclaved, filtered seawater. These species were Prochromadorella neapolitana De Man, Monhystera refringens Bresslau \& Stekhoven, and Monhystera disjuncta Bastian. Once per week, $5 \mathrm{ml}$ of a monoxenic diatom or bacterium culture isolated from $M$. integrifolia blade samples were added to the flasks of medium.

One half of these nematode stock cultures were maintained under simulated winter conditions at $5{ }^{\circ} \mathrm{C}$ with a $8 / 16 \mathrm{~h}\left(250 \mathrm{uW} \mathrm{cm}^{-2}\right) \mathrm{day} /$ night cycle; the remaining half were maintained under simulated summer conditions $\left(10^{\circ} \mathrm{C}, 16 / 8 \mathrm{~h}\right.$ day/night). Salinity was maintained at $31 \% \mathrm{~S}$ under both sets of conditions.

Bacterium and diatom species used in food preference experiments were isolated from detritus and scrapings from blade samples. Four bacterial species were isolated by standard microbiological techniques and then maintained on liquid (Difco Marine Broth) and solid media with added $1.0 \%$ Difco Bacto Agar at $10^{\circ} \mathrm{C}$ on a $16 / 8 \mathrm{~h}$ day/night cycle (Table 1). Eight marine diatom species were isolated by hand from blade scrapings using elongated Pasteur pipettes (Table 1) and incubated on sterile ' $\mathrm{S}$ ' medium (Lee et al., 1970 ) at $22^{\circ} \mathrm{C}$ on a $16 / 8 \mathrm{~h}$ day/night cycle. These diatom cultures were checked weekly for the presence of bacteria and marine fungi, and contaminated cultures were discarded.

The 'cafeteria' style experimental design (Fig. 1) (Gray, 1966; Gray and Johnson, 1970; Lee et al., 1977) was used to demonstrate the feeding preferences of the

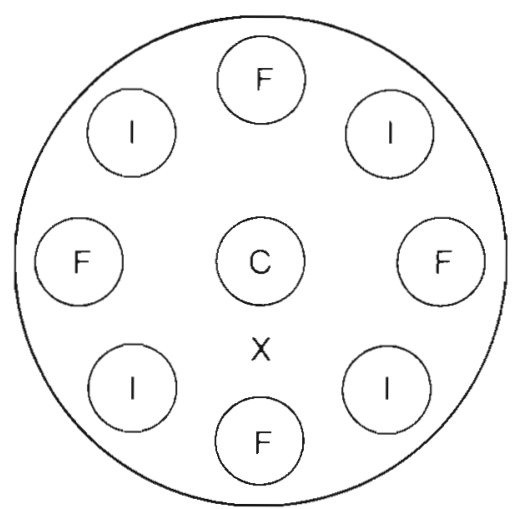

Fig. 1. 'Cafeteria' design of agar wells in Petri dish feeding preference experiments (F: food well, I: interwell, C: central well, $\mathrm{X}$ : outside)

nematodes found on Macrocystis integrifolia blades. Suspensions of diatom $\left(1.0 \times 10^{5} \pm 1.0 \times 10^{3}\right.$ individuals $/ m l)$ and bacterium species $\left(1.0 \times 1.0^{6} \pm 1.0 \times\right.$ $10^{4}$ individuals $/ \mathrm{ml}$ ) were inoculated into alternate peripheral food wells in an agar plate (Hobbie et al., 1977). One hundred adult nematodes (1:1 sex ratio) of 1 of the 3 species were placed in sterile seawater in the central well of the plate and covered with a cover slip. The agar plate was then carefully covered with a 0.5 $\mathrm{cm}$ deep layer of sterile seawater after which the coverslip was carefully removed. Four replicate plates and 1 control plate for each of the diatom or bacterium feeding experiments were established for each nematode species. The experiments were conducted under simulated summer and winter conditions. Pre-

Table 1. Diatom and bacterium (B1-B4) species isolated from Macrocystis integrifolia blades and used in feeding preference experiments

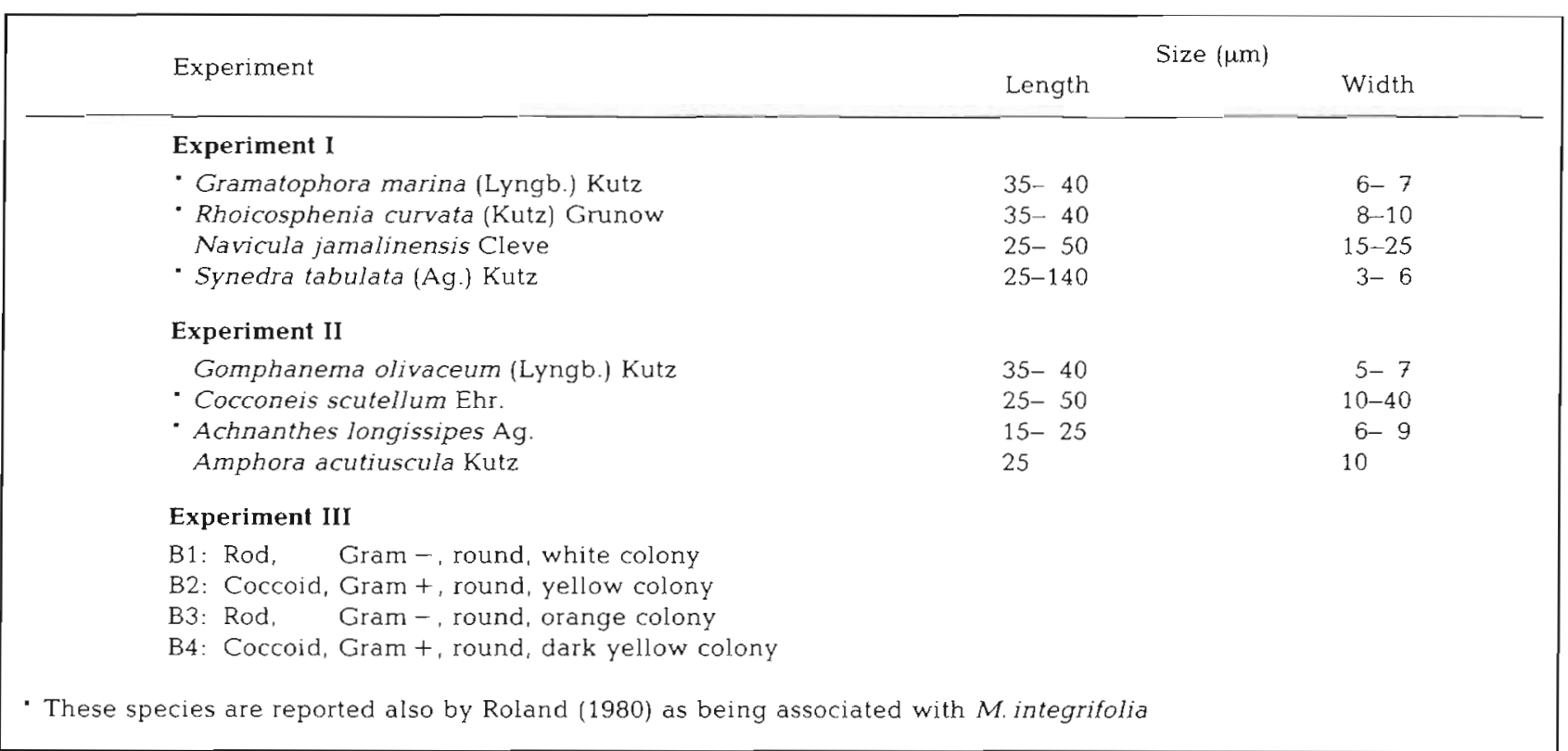


liminary experiments showed that the apparent response pattern of nematodes was completed by $72 \mathrm{~h}$. Hence, the nematode inoculated plates were left under these conditions for $72 \mathrm{~h}$ after which the number of nematodes present in each food and interwell and scattered on the agar outside of wells was counted and the nematodes sexed.

The data from the feeding performance experiments were analyzed using the chi-square, two-level ANOVA and the Student-Newman-Keuls tests (Sokal and Rohlf, 1969).

\section{RESULTS}

Under simulated summer conditions (Tables 2 to 4 ) all 3 nematode species accumulated significantly $(P<0.005)$ more at food wells than at interwells or at peripheral wells in the control plate. Also, observations on nematode behavior and of their gut contents during each experimental run indicated that all 3 species were actively feeding on food to which they had been preferentially attracted.

Greater numbers of Prochromadorella neapolitana accumulated at the diatom than at the bacterial wells (Table 2). In Experiment I, most nematodes were attracted to diatom species Gramatophora marina and Rhoicosphenia curvata. The number attracted to the wells containing Navicula jamalinensis was not sig- nificantly different from that recorded for the control wells. In Experiment II, almost $50 \%$ of the nematodes accumulated in food wells containing Cocconeis scutellum (Table 2). Fewer, but a significant number $(\mathrm{P}<0.05)$ of $P$. neapolitana, accumulated around diatom species Achnanthes longissipes and Amphora acutiuscula. Nematode accumulations in food wells with Gomphanema olivaceum were not significantly different from those in the control wells. P. neapolitana did not accumulate significantly more at wells containing bacterial species B1, B2 or B4 than at the control wells but a significant number $(P<0.05)$ accumulated at species B3. In Experiment III, a significant number $(P<0.05)$ of nematodes were found scattered outside the wells rather than accumulating at particular wells.

Monhystera refringens appeared to accumulate equally at diatom and bacterium food wells (Table 3) and in significantly greater numbers $(P<0.05)$ than at control wells. Significantly more nematodes $(P<0.05)$ accumulated at wells containing the diatom species Synedra tabulata than at any other food source. In Experiment II, $M$. refringens exhibited higher mean accumulations at wells containing Amphora acutiuscula and Achnanthes longissipes than at wells containing Gomphanema olivaceum (Table 3) but these accumulations were not significantly greater than those at the control wells due to the large standard deviation. When presented with bacterial sources, $M$. refringens was equally attracted $(\mathrm{P}<0.05)$ to bacterial

Table 2. Prochromadorella neapolitana. Male and female mean $(n=4)$ accumulation at wells containing diatom and bacterium species under simulated summer conditions

\begin{tabular}{|c|c|c|c|c|c|c|c|}
\hline \multirow[t]{2}{*}{ Expt. } & \multirow[t]{2}{*}{ Species } & \multicolumn{2}{|c|}{ Total } & \multicolumn{2}{|c|}{ Male } & \multicolumn{2}{|c|}{ Female } \\
\hline & & $\overline{\mathrm{x}}$ & S.D. & $\overline{\mathrm{X}}$ & S.D. & $\overline{\mathrm{x}}$ & S.D. \\
\hline \multirow[t]{7}{*}{ I } & Gramatophora marina & 37.00 & 8.60 & 19.50 & 6.61 & 17.50 & 4.51 \\
\hline & Rhoicosphenia curvata & 32.35 & 6.85 & 14.50 & 2.89 & 17.75 & 8.22 \\
\hline & Navicula jamalinensis & 5.50 & 3.70 & 3.75 & 2.75 & 1.75 & 0.96 \\
\hline & Synedra tabulata & 12.00 & 5.10 & 6.25 & 3.59 & 5.75 & 3.10 \\
\hline & Outside & 3.00 & 2.31 & 1.50 & 1.73 & 1.50 & 0.58 \\
\hline & Interwell & 2.56 & 2.50 & 1.13 & 1.15 & 1.44 & 1.75 \\
\hline & Control & 4.75 & 2.92 & 3.00 & 2.39 & 1.75 & 1.67 \\
\hline \multirow[t]{7}{*}{ II } & Gomphanema olivaceum & 3.25 & 2.22 & 2.50 & 2.38 & 0.75 & 1.50 \\
\hline & Cocconeis scutellum & 48.00 & 5.72 & 23.00 & 6.98 & 25.00 & 4.90 \\
\hline & Achnanthes longissipes & 19.00 & 4.90 & 9.75 & 0.96 & 9.25 & 4.99 \\
\hline & Amphora acutiuscula & 16.75 & 4.99 & 7.00 & 3.56 & 9.75 & 2.75 \\
\hline & Outside & 4.25 & 0.50 & 2.25 & 1.71 & 2.00 & 1.41 \\
\hline & Interwell & 2.19 & 1.28 & 1.38 & 1.20 & 0.81 & 0.91 \\
\hline & Control & 3.13 & 3.04 & 2.25 & 2.60 & 0.88 & 1.13 \\
\hline \multirow[t]{7}{*}{ III } & B1: Rod, & 4.00 & 2.94 & 1.50 & 1.73 & 2.50 & 3.70 \\
\hline & B2: Coccoid, Gram + & 2.75 & 2.06 & 1.50 & 1.30 & 1.25 & 1.89 \\
\hline & B3: Rod, Gram - & 15.75 & 3.95 & 9.75 & 2.63 & 6.00 & 1.83 \\
\hline & B4: Coccoid, Gram + & 3.75 & 2.87 & 1.50 & 1.73 & 2.25 & 2.87 \\
\hline & Outside & 64.00 & 12.03 & 29.50 & 4.65 & 34.50 & 9.18 \\
\hline & Interwell & 2.44 & 2.22 & 1.56 & 1.63 & 0.88 & 1.02 \\
\hline & Control & 3.63 & 3.66 & 2.38 & 2.26 & 1.25 & 1.58 \\
\hline
\end{tabular}


Table 3. Monhystera refringens. Male and female mean $(n=4)$ accumulation at wells containing diatom and bacterium species under simulated summer conditions

\begin{tabular}{|c|c|c|c|c|c|c|c|}
\hline \multirow[t]{2}{*}{ Expt. } & \multirow[t]{2}{*}{ Species } & \multicolumn{2}{|c|}{ Total } & \multicolumn{2}{|c|}{ Male } & \multicolumn{2}{|c|}{ Female } \\
\hline & & $\overline{\mathrm{x}}$ & S.D. & $\overline{\mathrm{x}}$ & S.D. & $\overline{\mathrm{X}}$ & S.D. \\
\hline \multirow[t]{7}{*}{ I } & Gramatophora marina & 10.50 & 5.20 & 6.75 & 4.65 & 3.75 & 2.63 \\
\hline & Rhoicosphenia curvata & 11.50 & 6.24 & 3.00 & 0.82 & 8.50 & 6.76 \\
\hline & Navicula jamalinensis & 14.00 & 4.55 & 5.50 & 3.70 & 8.50 & 6.19 \\
\hline & Synedra tabulata & 40.00 & 8.29 & 21.75 & 6.18 & 18.25 & 12.53 \\
\hline & Outside & 10.00 & 3.37 & 7.00 & 2.45 & 3.00 & 1.41 \\
\hline & Interwell & 3.50 & 2.80 & 1.50 & 1.26 & 2.00 & 2.19 \\
\hline & Control & 3.25 & 3.11 & 2.00 & 2.51 & 1.25 & 1.49 \\
\hline \multirow[t]{7}{*}{ II } & Gomphanema olivaceum & 9.25 & 3.10 & 6.25 & 4.79 & 3.00 & 2.16 \\
\hline & Cocconeis scutellum & 15.00 & 6.98 & 7.50 & 2.74 & 7.50 & 6.56 \\
\hline & Achnanthes longissipes & 21.75 & 9.36 & 7.25 & 4.11 & 14.50 & 11.00 \\
\hline & Amphora acutiuscula & 22.25 & 6.85 & 12.75 & 7.14 & 9.50 & 6.24 \\
\hline & Outside & 12.50 & 2.65 & 6.50 & 3.87 & 6.00 & 4.24 \\
\hline & Interwell & 4.81 & 2.40 & 2.44 & 1.79 & 2.38 & 2.06 \\
\hline & Control & 3.50 & 2.14 & 1.50 & 1.69 & 2.00 & 2.00 \\
\hline \multirow[t]{7}{*}{ III } & B1: Rod, Gram - & 9.25 & 3.50 & 5.00 & 2.71 & 4.25 & 2.50 \\
\hline & B2: Coccoid, Gram + & 21.50 & 4.93 & 10.25 & 3.40 & 11.25 & 6.08 \\
\hline & B3: Rod, Gram - & 24.00 & 5.29 & 8.00 & 2.94 & 16.00 & 5.94 \\
\hline & B4: Coccoid Gram + & 17.75 & 2.63 & 10.75 & 3.69 & 6.50 & 6.03 \\
\hline & Outside & 13.00 & 3.92 & 8.00 & 3.74 & 5.00 & 3.46 \\
\hline & Interwell & 3.75 & 3.07 & 2.00 & 2.28 & 1.75 & 1.61 \\
\hline & Control & 4.50 & 3.21 & 2.38 & 2.07 & 2.13 & 2.30 \\
\hline
\end{tabular}

Table 4. Monhystera disjuncta. Male and female mean ( $(=4)$ accumulation at wells containing diatom and bacterium species under simulated summer conditions

\begin{tabular}{|c|c|c|c|c|c|c|c|}
\hline \multirow[t]{2}{*}{ Expt. } & \multirow[t]{2}{*}{ Species } & \multicolumn{2}{|c|}{ Total } & \multicolumn{2}{|c|}{ Male } & \multicolumn{2}{|c|}{ Female } \\
\hline & & $\bar{x}$ & S.D. & $\overline{\mathrm{X}}$ & S.D. & $\overline{\mathrm{x}}$ & S.D. \\
\hline \multirow[t]{7}{*}{ I } & Gramatophora marina & 9.75 & 4.43 & 5.50 & 4.36 & 4.25 & 2.50 \\
\hline & Rhoicosphenia curvata & 5.00 & 2.94 & 1.00 & 0.82 & 4.00 & 3.27 \\
\hline & Navicula jamalinensis & 7.75 & 4.99 & 5.25 & 3.87 & 2.50 & 3.00 \\
\hline & Synedra tabulata & 21.75 & 6.08 & 12.25 & 6.70 & 9.50 & 5.57 \\
\hline & Outside & 45.50 & 19.23 & 20.00 & 15,01 & 25.50 & 10.41 \\
\hline & Interwell & 2.56 & 2.16 & 1.50 & 1.46 & 1.06 & 1.53 \\
\hline & Control & 2.38 & 2.33 & 2.00 & 2.14 & 0.38 & 0.52 \\
\hline \multirow[t]{7}{*}{ II } & Gomphanema olivaceum & 8.75 & 3.30 & 5.25 & 3.31 & 3.50 & 3.00 \\
\hline & Cocconeis scutellum & 9.50 & 5.45 & 7.25 & 5.00 & 2.25 & 1.26 \\
\hline & Achnanthes longissipes & 0.50 & 0.58 & 0.25 & 0.50 & 0.25 & 0.50 \\
\hline & Amphora acutiuscula & 5.50 & 2.52 & 3.00 & 4.08 & 2.50 & 2.38 \\
\hline & Outside & 63.00 & 6.27 & 25.25 & 3.59 & 27.75 & 5.50 \\
\hline & Interwell & 3.19 & 2.56 & 2.25 & 2.18 & 0.94 & 1.12 \\
\hline & Control & 3.38 & 2.83 & 2.00 & 2.07 & 1.38 & 1.41 \\
\hline \multirow[t]{7}{*}{ III } & B1. Rod, Gram - & 18.00 & 5.90 & 7.50 & 6.60 & 10.50 & 1.30 \\
\hline & B2: Coccoid, Gram + & 19.25 & 3.86 & 8.50 & 4.93 & 10.75 & 5.62 \\
\hline & B3: Rod, Gram - & 27.75 & 7.27 & 19.25 & 5.44 & 8.50 & 4.51 \\
\hline & B4: Coccoid, Gram + & 14.75 & 2.63 & 6.25 & 2.06 & 8.50 & 1.91 \\
\hline & Outside & 9.75 & 4.27 & 3.75 & 2.50 & 6.00 & 3.37 \\
\hline & Interwell & 2.63 & 1.78 & 1.19 & 0.66 & 1.44 & 1.55 \\
\hline & Control & 4.00 & 2.00 & 2.50 & 1.31 & 1.50 & 1.93 \\
\hline
\end{tabular}

species B2, B3, and B4 but had a lower mean accumulation at B1 food wells. The nematode accumulations in the bacterial wells were significantly greater $(P<0.05)$ than those found in the control wells.
Monhystera disjuncta exhibited a strong tendency to accumulate at bacterial wells rather than at wells with diatoms and they tended to accumulate more in the wells with the rod-shaped species B3 rather than in 
those with coccoid bacteria species B2 or B4 (Table 4). A significant number $(\mathrm{P}<0.05)$ of $M$. disjuncta accumulated at diatom species Synedra tabulata but this was subsequently attributed to bacterial contamination. In both Experiments I and II, with diatom food wells, a significant $(P<0.05)$ number of nematodes were scattered outside the wells rather than accumulating at one of the food wells.

Results for the simulated winter conditions showed all 3 nematode species to have the same overall pattern of accumulation as for the simulated summer conditions except that the mean number of nematodes found in a particular food well was lower. In general, under winter and summer conditions, males and females of the 3 species responded with equal facility to the various food types.

\section{DISCUSSION}

Each nematode species exhibited some distinct food preferences as measured by their accumulation at particular foods when given a set of alternatives. In particular, Prochromadorella neapolitana showed a particular preference for diatoms (Table 2), Monhystera disjuncta a preference for bacteria (Table 4) and $M$. refringens exhibited no general preference for bacteria or diatoms (Table 3). However, in experiments (Table 2, Experiment III; Table 4, Experiments I and II) where no strong preferences were manifest, large numbers of nematodes remained scattered on the medium outside of the wells, apparently not responding to any one stimulus.

Monhystera species commonly contain detritus throughout the gut and in previous feeding experiments they have been successfully maintained on the bacteria Arthrobacter sp., Pseudomonas sp., Vibria sp. and Elavobacterium sp. (Chitwood and Murphy, 1964). Chromadora macrolaimoides is very selective in ingestion and digestion of algae. Of 20 species of algae tested only 11 were utilized by this nematode and 5 sustained nematode growth to 10 generations (Tietjen and Lee, 1973). A similar study by Tietjen and Lee (1977b) suggested that not only was selective ingestion a significant factor in nematode feeding habits, but so also was selective digestion. Prochromadorella neapolitana, an epigrowth feeder according to Wieser (1952), selected primarily wells with diatom species, especially Cocconeis scutellum, Gramatophora marina and Rhoicosphenia carvata (Table 2). When exposed to a range of bacteria $P$. neapolitana responded preferentially to only the rod-shaped bacteria species, B3. Chromadorina germanica similarly was attracted preferentially to several diatom species but to only 1 bacterium (Tietjen and Lee, 1977a; Lee et al., 1977).
Monhystera disjuncta and $M$. refringens, selective and non-selective deposit feeders, respectively (Wieser, 1952), exhibited different feeding preferences (Tables 3 and 4). $M$. disjuncta preferred particular bacterial rather than diatomaceous species. Although there was a significant accumulation $(P<0.05)$ of $M$. disjuncta to the rod-shaped B3 species, there was no observed preference to rod-shaped rather than coccoid bacteria.

Rhabditis marina feeds on the rod bacteria Pseudomonas sp. and Elavobacterium sp., rather than on the coccoid species Micrococcus sp. (Lee et al., 1970). Wilt et al. (1973) found that bacteriophagus nematodes preferentially migrated toward and fed on rod (Vibrio sp.) rather than coccoid species. However, food size is a significant factor in determining food preferences for the bacteriophagus nematodes (Alongi and Tietjen, 1980) and the diatom species used here may have been too large for Monhystera disjuncta to be ingested successfully.

Monhystera refringens appeared to be more generalist in its food preferences than $M$. disjuncta; it was attracted to diatom and bacterial species.

Tables 2 to 4 suggest that Prochromadorella neapolitana and Monhystera disjuncta are quite selective in their feeding habits and, hence, spatial and seasonal variations in abundance of the food types associated with $M$. integrifolia may account for the distinctive patterns of abundance and distribution of these dominant nematode species on kelp. The diatom species Cocconeis scutellum occurs in great abundance in April to July (Roland, 1980), i.e. a time of increasing abundance of $P$. neapolitana (Trotter, 1981). The decreased abundance of this nematode in late summer corresponds with a decreasing abundance of this diatom in August. Furthermore, the increased relative abundance of the diatom Rhoicosphenia curvata in October may explain the sudden increase in $P$. neapolitana numbers in November (Trotter, 1981). $P$. neapolitana showed little or no preference for bacteria and probably does not utilize this food source, although both rod and coccoid forms occur on the blades of Macrocystis integrifolia throughout the year (Roland, 1980). In part, this may be related to food size because Alongi and Tietjen (1980) found that epigrowth feeders utilize bacteria when this food is attached to a substrate.

The high relative abundance of Monhystera disjuncta throughout most of the year may, in part, be related to the corresponding year-round population of bacteria on the blades. Previous studies have indicated that variations in marine nematode numbers are directly related to the varying size of bacterial populations (Boucher and Chamroux, 1976; Chamroux et al., 1977). Preference of $M$. disjuncta for bacteria, lack of 
attraction to diatoms and its short generation time (Gerlach and Schrage, 1971), may explain the high abundance of this species and its seasonal distribution associated with population peaks of bacteria (Trotter, 1981). Several investigators have observed large bacterial populations, primarily of the rod type associated with marine algae and they were often found most abundant on the older, deteriorating parts of the plant (Laycock, 1974; Kong and Kwong-yu Chan, 1979; Mazure and Field, 1980). Most investigators of nematode feeding preference have observed that the selective and non-selective deposit feeders survive and reproduce on rod-shaped bacterial sources (Hopper and Meyers, 1967; Tietjen, 1967; Tietjen and Lee, $1973,1977 \mathrm{~b}$ ). Therefore, the high relative abundance of $M$. disjuncta throughout the year and its occurrence on the older, lower blades of Macrocystis integrifolia may be related to the bacterial populations even though it did not show a marked preference for rodshaped bacteria. Epiphyte populations tend to increase with tissue age (North, 1971; Ballantine, 1979) and most nematodes are found associated with deteriorating heavily encrusted blades (Wing and Clendinning, 1971). The lower blades of $M$. integrifolia are the most heavily encrusted with epiphytes; here most nematodes are found (Trotter, 1981).

It is more difficult to relate the general feeding preferences of Monhystera refringens to the distribution and abundance of this nematode. Nevertheless, Table 3 shows a significant preference $(\mathrm{P}<0.05)$ of $M$. refringens for the diatom Synedra tabulata which is most abundant during late summer and early fall (Roland, 1980). This corresponds to the observed increases in abundance of $M$. refringens that reached their highest levels in fall (Trotter, 1981). The other diatom species presented to $M$. refringens occur during summer on the seaweed in relatively low percentages (Roland, 1980) and are relatively less attractive to this nematode. Cocconeis scutellum is an exception in that it is the most abundant diatom species during this period. However, $M$. refringens was only moderately attracted to this diatom, which was the preferred food of Prochromadorella neapolitana and was frequently observed in the gut of $P$. neapolitana from field samples and laboratory experiments. Variations in abundance of $M$. refringens throughout the year are likely related to a combination of factors, including bacterial and diatom food sources.

If marine nematodes are as selective in their feeding habits as these results and those of other studies suggest, the spatial and temporal variations in the abundance of epiphytic microorganisms are likely major factors affecting patterns of abundance and distribution. Selective feeding by nematodes on different food types may diminish or perhaps in some instances even elimi- nate competition within a particular habitat. This would enable cohabitation in a small area, such as algal blades, by a variety of nematode species which, on the basis of buccal morphology, would appear to feed on the same food types. This may be the case for Monhystera disjuncta and $M$. refringens and may explain the dominance of species types with Wieser's (1952) epigrowth feeding classification. The study of Alongi and Tietjen (1980) on the competitive interac tions of nematodes with similar buccal morphologies provides an additional perspective to this problem. Further data are needed on the competitive interactions between marine nematodes species themselves and between them and other organisms in order to ascertain the full role of food and feeding types on the populations and distribution of free-living nematodes on seaweeds.

Acknowledgements. The authors acknowledge Bruce Hopper (Canada Agriculture, Ottawa) for confirming species identification, Sebastian Gerlach (Kiel) for helpful advice with the script, and the Natural Sciences and Engineering Research Council of Canada for financial support of the project.

\section{IITERATURE CITED}

Alongi, D. M., Tietjen, J H. (1980). Population growth and trophic interactions among free-living marine nematodes. In: Tenore, K. R., Coull, B. (ed.) Marine benthic dynamics. University of South Carolina Press, Columbia, p. 151-166

Ballantine, D. L. (1979). The distribution of algal epiphytes on macrophyte hosts off shore from La Parguera, Puerto Rico. Botanica mar. 22: 107-111

Boucher, G., Chamroux, S. (1976). Bacteria and meiofauna in experimental sand ecosystems. I. Materials and preliminary results. J. exp. mar. Biol. Ecol. 24: 237-249

Chamroux, S., Boucher, G., Boudin, P. (1977). Etude experimentale d'un ecosystème sableux. II. Evolution des population de bacteries et de méiofaunes. Helgoländer wiss. Meeresunters. 30: 163-177

Chitwood, B. G., Murphy, D. G. (1964). Observations on two marine monhysterids - their classification, cultivation and behaviour. Trans. Am. microsc. Soc. 83: 311-329

Gerlach, S. A., Schrage, M. (1971). Life cycles in marine meiobenthos. Experiments at various temperatures with Monhystera disjuncta and Theristus pertenuis (Nematoda). Mar. Biol. 9: 274-280

Gray, J. S. (1966). The attractive factor of intertidal sands to Protodrilus symbioticus. J. mar. biol. Ass. U. K. 46: $627-645$

Gray, J. S., Johnson, R. M. (1970). The bacteria of a sandy beach as an ecological factor affecting the interstitual gastrotrich Turbanella hyalina, Schultze. J. exp. mar. Biol. Ecol, 4: 119-133

Hobbie, J. E., Daley, R. J, Jasper, S. (1977). Use of nucleopore filters for counting bactería by fluorescence microscopy. Appl. environ. Microbiol. 33: 1225-1228

Hopper, B. E., Meyers, S. P. (1967). Foliicolus marine nematodes on turtle grass. Thalassia testudinum Konig, in Biscayne Bay, Florida. Bull. mar. Sci. 17: 471-517 
Kong, M. K., Kwong-yu Chan (1979). A study on the bacterial flora isolated from marine algae. Botanica mar. 22: 83-97

Laycock, R. A. (1974). The detrital food chain based on seaweeds. I. Bacteria associated with the surface of Laminaria fronds. Mar. Biol. 25: 223-231

Lee, J. J., Tietjen, J. H., Mastropaolo, C., Rubin, H. (1977). Food quality and the heterogeneous spatial distribution of meiofauna. Helgoländer wiss. Meeresunters. 30: 272-282

Lee, J. J., Tietjen, J. H., Stone, R. J., Muller, W. A., Rullman, J., McEnery, M. (1970). The cultivation and physiological ecology of members of salt marsh epiphytic communities. Helgoländer wiss. Meeresunters. 20: 126-156

Mazure, H. G. F., Field, J. G. (1980). Density and ecological importance of bacteria on kelp fronds in an upwelling region. J. exp. mar. Biol. Ecol. 43: 173-182

Moore, P. G. (1971). The nematode fauna associated with holdfasts of kelp (Laminaria hyperborea) in northwest Britain. J. mar. biol. Ass. U. K. 51: 589-604

North, W. J. (1971). Biology of giant kelp beds (Macrocystis) in California. J. Cramer, Lehre

Roland, W. (1980). Epiphytism and endophytism of Macrocystis integrifolia and Nereocystis luetkeana: seasonality, succession and tactics on temporary living substrate. M. Sc. thesis, Simon Fraser University

Sokal, R. R., Rohlf, F. J. (1969). Biometry. W. H. Freeman Co., San Francisco

Tietjen, J. H. (1967). Observations on the ecology of the marine nematode, Monhystera filicaudata, Allgen, 1929. Trans. Am. microsc. Soc. 86: 304-306

Tietjen, J. H., Lee, J. J. (1973). Life history and feeding habits of the marine nematode Chromadora macrolaimoides, Steiner. Oecologia (Berl.) 12: 303-314

Tietjen, J. H., Lee, J. J. (1977a). Life histories of marine nematodes. Influences of temperature and salinity on the reproductive potential of Chromadorina germanica, Butschli. Mikrofauna Meeresboden 61: 263-270

Tietjen, J. H., Lee, J. J. (1977b). Feeding behaviour of marine nematodes. In: Coull, B. E. (ed.) Ecology of the marine benthos. University of South Carolina Press, Columbia

Trotter, D. (1981). Distribution and feeding preferences of free-living nematodes associated with the kelp, Macrocystis integrifolia (Laminariales). M. Sc. thesis, Simon Fraser University

Wieser, W. (1952). Die Beziehungen zwischen Mundhöhlengestalt, Emährungsweise und Vorkommen bei freilebenden marinen Nematoden. Ark. Zool. 4: 439-484

Wilt, G. R., Joshi, M. M., Metcalf, J. (1973). Studies on the interaction of bacteria and nematodes. Water Resources Inst. Bull. 10, Auburn Univ., Alabama

Wing, B. L., Clendinning, K. A. (1971). Kelp surfaces and associated invertebrates. In: North, W. J. (ed.) The biology of giant kelp beds (Macrocystis) in California. J. Cramer, Lehre 